\title{
Transatlantica
}

Revue d'études américaines. American Studies Journal

Géraldine Chouard, Eudora Welty et la photographie: Naissance d'une vision, Paris, Éditions Michel Houdiard, 2012, 178 pages

\section{Miles Orvell}

\section{(2) OpenEdition}

\section{Journals}

Édition électronique

URL : https://journals.openedition.org/transatlantica/5896

DOI : $10.4000 /$ transatlantica.5896

ISSN : $1765-2766$

Éditeur

Association française d'Etudes Américaines (AFEA)

Référence électronique

Miles Orvell, "Géraldine Chouard, Eudora Welty et la photographie: Naissance d'une vision, Paris, Éditions Michel Houdiard, 2012, 178 pages », Transatlantica [En ligne], 2 | 2012, mis en ligne le 09 mars 2013, consulté le 06 avril 2023. URL : http://journals.openedition.org/transatlantica/5896 ; DOI : https:// doi.org/10.4000/transatlantica.5896

Ce document a été généré automatiquement le 6 avril 2023.

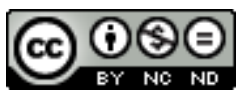

Creative Commons - Attribution - Pas d'Utilisation Commerciale - Pas de Modification 4.0 International - CC BY-NC-ND 4.0

https://creativecommons.org/licenses/by-nc-nd/4.0/ 


\title{
Géraldine Chouard, Eudora Welty et la photographie: Naissance d'une vision, Paris, Éditions Michel Houdiard, 2012, 178 pages
}

\author{
Miles Orvell
}

1 I recall my shock, in 1971, on discovering Eudora Welty's first collection of photographs, One Time, One Place: A Mississippi Album. I had been reading Welty in graduate school as one of the great Southern writers to follow in the tracks of Faulkner, along with Katherine Ann Porter, Truman Capote, Carson McCullers, and Flannery o'Connor, an amazing generation of writers who had given the South the strongest regional presence in post World-War II American letters. Welty in particular offered perhaps the most idiosyncratic voice and vision, focused on indelibly bizarre characters, sharp observations of setting, and a tense style that hovered on the edge of the comic and the grotesque. But Welty seemed to exist so much by virtue of her extraordinary language, that to discover the archive of her visual work-the photographs she'd taken in the mid-1930s-forced us to reconsider the whole career. (And of course it was still unfolding in the seventies.)

Welty was a shrewd critic, and her own sense of her work as a photographer, when she introduced it in 1971, described beautifully what she was doing with her camera and how it related in fundamental terms to her fiction. She was not, she tells us pointedly in the essay that introduces One Time, One Place, a government photographer. She was employed as a "publicity agent, junior grade," for the State of Mississippi, under the Works Progress Administration of the U.S. Government, instituted as part of Roosevelt's New Deal to provide jobs to a wide range of otherwise unemployed people, skilled and unskilled. Traveling around the state on various projects, talking with a range of residents from all counties, Welty began taking photographs for her own amusement, and also, as she puts it, as a "shy person's protection." That suggests a wall between photographer and subject, but Welty used the camera as a way of relating to 
people, enabling her to develop a bond of trust with her subjects, especially her African American ones. As she astutely notes, "[i]n taking all these pictures, I was attended, I now know, by an angel-a presence of trust. In particular, the photographs of black persons by a white person may not testify soon again to such intimacy. It is a trust that dates the pictures now, more than the vanished years." That trust is indeed evident in the images of African Americans Welty reproduces in One Time, One Place, in the frank and sometimes mirthful expressions of her subjects, looking into the camera, and in their relaxed postures, young and old, as they work and play in their hometowns and rural areas. But the trust was not at all the product of that time, as one can see in the contemporaneous accounts of black and white relations that are present in Richard Wright's Black Boy or-from the other side of the racial divide-in James Agee's narrative of his encounter with a black couple on a country road, early in Let Us Now Praise Famous Men. The source of that trust, as Welty understood, is that she was, by appearance and voice, an insider, a Mississippian, and she connected with people in a way that was simply beyond the capacity of any of the photographers, who represented "the government" and who worked as itinerants, just passing through. Welty offered her photographs in 1971 "not as a social document but as a family album."

Welty's more familiar approach to her subjects is founded on her interest in them as individuals, rather than-as was the case with the documentary approach of the Farm Security Administration crew-as types, as representatives of a social condition. And Welty's openness to the individuality of her subjects would also teach her a kind of attention and curiosity that would translate into her fiction, where the process of understanding individuality and eccentricity is at the heart of the fictional enterprise, for both writer and reader.

4 Almost twenty years passed, from the 1971 publication of Welty's early photographic work, to the gradual revelation of the full range of her camera productions: a limited edition of her photos appeared in 1985 called In Black and White (Lord John Press); Eudora Welty: Photographs appeared in 1989 with a foreword by writer Reynolds Price (University Press of Mississippi); a selection of her many cemetery photos came out in 2000 (Country Churchyards, University Press of Mississippi); and in 2009 Pearl Amelia McHaney edited Eudora Welty as Photographer, a volume featuring essays by noted photo-historians Sandra S. Phillips and Deborah Willis (University Press of Mississippi). Meanwhile, Welty's photography had been the subject of several articles by mostly American scholars. But not until the publication of Geraldine Chouard's Eudora Welty et la photographie: Naissance d'une vision have we had a full-scale treatment of Welty the photographer and of the importance of photography to Welty's literary imagination. Chouard has been working on Welty for nearly twenty years, and her study bears the mark of her maturity as a scholar: it is a nuanced treatment of Welty and photography, from multiple angles, demonstrating without question the necessity of considering the camera as a central component of the writer's imagination and apprehension of the world.

5 Chouard builds her subject logically, beginning with a biographical first chapter that places a Kodak in Welty's hands when she was 13 and introduces us to the madcap side of Welty (who loved disguising herself as Groucho Marx); we learn also how serious was Welty's pictorial passion, which would lead her to solicit one of the great women photographers of her time, Berenice Abbott, for instruction-without result. Even so, several of Welty's works, taken in New York City, clearly show Abbott's influence, in the 
angular treatment of urban scenes, with foreground and background dramatically juxtaposed. Chouard places Welty's photographs of Southern Blacks in the context of existing Thirties photography-by Doris Ulmann and Margaret Bourke-White-whose work, as Welty saw it, was condescending. A second chapter provides a broader context for Welty as photographer-the work of the Farm Security Administration that began in 1935 under the direction of Roy Stryker, who brought in such photographers as Walker Evans, Dorothea Lange, Arthur Rothstein, Marion Post Wolcott, Esther Bubley, John Vachon, and others. Chouard offers in this chapter an ample consideration of Welty's photographic subjects and characteristic approaches, with detailed readings of many photographs that are not, however, reproduced in the book itself.

6 In her third chapter, Chouard turns to the relationships between the photographs and the fiction, exploring the many references to photography in Welty's work, including a lengthy discussion of one of the writer's great stories, "Why I Live at the P.O." Chouard uses multiple theoretical lenses in her reading of Welty's fiction, with Roland Barthes, Walter Benjamin, and Régis Debray giving noteworthy, if predictable, service; but Freud figures interestingly as well, especially in discussing Losing Battles, where Chouard develops a psychological and biographical reading, referencing Freud's use of the metaphor of photography (in Introduction to Psychoanalysis, 1916) to explain the relationship of the subconscious to the conscious, where the former is a kind of hidden negative, developed and brought to light when it passes into the "positive" phase. This theme surfaces more directly in Chapter IV, where Chouard discusses Welty's autobiographical writings and the importance of her family history to the structural forms of her imagination.

7 Welty criticism has frequently approached the writer in terms of her famously articulated "sense of place," and in Chapter V, Chouard offers a discussion that ingeniously explores place through a comparison of Welty's American vision, vis-à-vis the geographical inspiration of several photographers she admired-Kertesz (Paris), Cartier-Bresson (Russia), Leni Riefenstahl (Germany and Africa), and William Eggleston, her Southern confrère. And finally, Welty's obsession with cemeteries concludes this last chapter, building inevitably on the association of photography with time, death, and memory.

There are forty illustrations in Eudora Welty et la photographie, all of them published previously in earlier collections of her work. We see a decent sampling of the range of Welty the photographer, but it is a rather limited selection, in view of the many references throughout the study to work that is not there to see. In short, this is a book for serious students of Welty, who already have some familiarity with her oeuvre as a photographer and, ideally, copies of the earlier collections of her photographic work at hand. It is also a book that will stand as a major study of the influence of photography on one of the great writers of the twentieth century. 
INDEX

Thèmes : Recensions

\section{AUTEUR}

MILES ORVELL

Temple University, Philadelphia (PA) 